\title{
Izidinski krug egipatskih ženskih božanstava Prolegomena
}

\begin{abstract}
Kult egipatske božice Izide imao je univerzalni karakter i nije se zadržao u prostornim i vremenskim granicama faraonskog Egipta. Izida je poprimila različite funkcije i povezivala se, putem svojih temeljnih značajki, sa ženskim božanstvima prednje Azije, Fenikije, Sirije, Male Azije, a potom Grčke i Rima. Epikleza Mȳriónymos, "tisućuimena", najbolje dočarava božičinu mnogoliku prirodu.
\end{abstract}

Za kratko izlaganje koje ima karakter uvoda odabrao sam neke od brojnih odrednica koje se vezuju uz egipatski Izidin kult koji su povijesne okolnosti pretvorile u univerzalni kult. Bit ćemo, dakle, na razmeđu Egipta i univerzalnog i na nekim bitnim odrednicama Izidina kulta pogledati kako se on preobražavao. To se očituje u tri modela: Izida Koūrotróphos, ona koja drži u krilu maloga Hora, Izida Mȳriónymos ili Polȳónymos - ona koja ima mnoga imena, te Izida kao božanstvo plodnosti u kozmičkim funkcijama.

Izida Koürotróphos prvi je standardizirani ikonografski model božanske majke koja drži božansko dijete u naručju. Nađu se i drugdje figure koje bi se mogle interpretirati u tom smislu, ali nisu standardizirane. Motiv Izide Koūrotróphos u egipatskoj se plastici javlja pretežito u kasnijim razdobljima i ponajviše se vezuje uz malu plastiku. U monumentalnoj egipatskoj plastici taj je motiv gotovo izočan. Javlja se ponegdje na figurama srednje veličine, od alabastra, međutim, ponajviše su to male figurice od bronce, terakote ili drugog materijala. Imale su apotropejsko značenje i široku rasprostranjenost $u$ kasnom razdoblju.

Za navedeni je model karakteristično da se najčešće Izida prikazuje s hatoričkim naglavkom - kravljim rogovima i sunčanom pločom. To pokazuje drevno egipatsko spajanje ženskih božanstava koja povezuje karakter majčinstva i plodnosti. Naime, teško je odvojiti Izidine funkcije od onih božice Hathor: iako se kaže da je Izida simbol majčinstva u suptilnijem smislu, Hathor je simbol seksualnosti, te su konotacije ograničene. Primjerice, Hathor ima i solarni aspekt predstavljan u vidu sunčanog diska. Već se, dakle, u drevnom Egiptu povezuju te dvije božice sličnih funkcija i predstavljaju kao Velike Božice. Stapaju se u jedno božanstvo Izida-Hathor, no u egipatskoj teologiji ipak zadržavaju svoje identitete. 
Posebno je zanimljivo da je u kasnijim razdobljima Izida poprimila sve šire funkcije i povezivala se, putem svojih temeljnih značajki, sa ženskim božanstvima prednje Azije, Fenikije, Sirije, Male Azije. To je Izidin put prema univerzalnosti i asimiliranju niza ženskih božanstava. Tu valja spomenuti poznati Kanopski dekret kojim se divinizira rano preminula kći Ptolemeja III. - Berenika. Određuje se pritom njezin ikonografski lik koji podrazumijeva klasje, uraeus - kobru kao znak sunčane snage te stabljiku papirusa zbog stvaranja kriptograma. Divinizirana Berenika se vrlo brzo stopila s Izidom. Proširio se kult Izide Berenike, a ona se povezuje s drugim ženskim božanstvima sa spomenutih prednjoazijskih prostora. Vrlo staro božanstvo, Baalat iz Biblosa, Dama Biblosa, nije imala standardizirani ikonografski oblik, međutim, upravo zbog toga poprima obličja bilo Izide, bilo Hathor - egipatskih božica putem Berenikina kulta. U Fenikiji će Berenika biti štovana kao djevičanska Aštarte. Stvorio se, dakle, model ženskog materinskog božanstva koji je toliko univerzalan, da će vrlo lako "usisati" druga božanstva s navedenih područja.

Mȳriónymos, "tisućuimena", Izidina je epikleza iz grčko-rimskog doba. Znači tisućuimena, ali i beskrajna. U Egiptu, naime, broj deset tisuća označava bezmjernost, beskrajnost. Smatra se da su epiklezu Mȳriónymos stvorili egipatski svećenici u 1. stoljeću prije Krista da bi izrazili egipatsko-grčki orijentalni sinkretizam na čijem je čelu Izidin lik. No, epitet "tisućuimena" po postanku je vrlo drevan. Naime, već u Knjizi mrtvih, za 18-19. dinastije, Izida se spominje kao božanska u svim svojim imenima. Izida, dakle, nije samo Izida, nego je u imenima različitih ženskih božanstava kao emanacija ženskog načela. U poznatom Apulejevu tekstu kaže se da se Izida štuje kod raznih naroda pod raznim imenima: kod Sirijaca kao Aštarte-Artemida, kod Likijaca kao Leto, kod Tračana kao Majka Bogova, kod Grka kao Hera, Afrodita, Reja ili Demetra. Izidinski koncept se, dakle, proširio i penetrirao u gotovo sva ženska majčinska božanstva istočnoga Sredozemlja.

Aspekt Izidine plodnosti u kozmičkim funkcijama spominje se u raznim aretalogijama koje su nastale prema modelu Memfiske aretalogije. To su spjevovi koji se datiraju od 1. stoljeća prije Krista do 3. stoljeća poslije Krista. U njima se Izida javlja u prvome licu izjavljujući tko je ona i nabrajajući sve svoje božanske funkcije, ili se, pak, o njoj i njezinim karakteristikama govori u trećem licu. U tim se aretalogijama naglašava da se Izida uzdiže u zviježđe Psa. To je, jasno, u vezi s helijačkom pojavom Sotisa koji izaziva poplavu Nila. Time se Izida sa svoje kozmičke dimenzije direktno upleće $u$ temeljnu zemaljsku dimenziju plodnosti koja je vezana uz poplave Nila. U aretalogijama se također spominje da je Izida spojila muškarca i ženu, da je ona koja stvara njihov odnos, da je promovirala da djeca štuju roditelje i tako, dakle, stvorila obiteljski nukleus iz kojega proizlazi čitav kompleks koji se vezuje na obitelj, temeljnu česticu ljudskog društva. 


\section{The Isiac circle of Egyptian female goddesses Prolegomena}

The cult of the Egyptian goddess Isis had the universal character and it didn't stay within the space and time boundaries of the pharaonic Egypt. Isis adopted different functions and was related, through her basic features, with female deities of Phoenycia, Syria, Asia Minor and later Greece and Rome. The epiclesis Mȳriónyma, "of ten thousand names", evokes the Goddess' multiform nature in the best way.

Key words: Egypt, cult, Isis, Mȳriónimos, fertility Ključne riječi: Egipat, kult, Izida, Mȳriónymos, plodnost 


\section{FILOZOFSKI FAKULTET SVEUČILIŠTA U ZAGREBU \\ ZAVOD ZA HRVATSKU POVIJEST \\ INSTITUTE OF CROATIAN HISTORY \\ INSTITUT FÜR KROATISCHE GESCHICHTE}

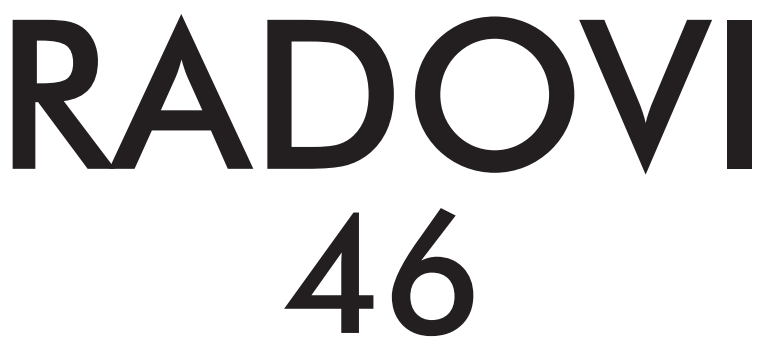

ZAVOD ZA HRVATSKU POVIJEST

FILOZOFSKOGA FAKULTETA SVEUČILIŠTA U ZAGREBU

FF press

ZAGREB 2014. 


\title{
RADOVI ZAVODA ZA HRVATSKU POVIJEST FILOZOFSKOGA FAKULTETA SVEUČILIŠTA U ZAGREBU
}

\author{
Knjiga 46 \\ Izdavač / Publisher \\ Zavod za hrvatsku povijest \\ Filozofskoga fakulteta Sveučilišta u Zagrebu \\ FF-press \\ Za izdavača / For Publisher \\ Vlatko Previšić \\ Glavni urednik / Editor-in-Chief \\ Hrvoje Gračanin \\ Uredništvo / Editorial Board
}

Bruna Kuntić-Makvić (stara povijest/ancient history), Zrinka Nikolić Jakus (srednji vijek/ medieval history), Hrvoje Petrić (rani novi vijek/early modern history), Željko Holjevac (moderna povijest/modern history), Tvrtko Jakovina (suvremena povijest/contemporary history),

Silvija Pisk (mikrohistorija i zavičajna povijest/microhistory and local history),

Zrinka Blažević (teorija i metodologija povijesti/theory and methodology of history)

Međunarodno uredničko vijeće / International Editorial Board

Denis Alimov (Sankt Peterburg), Živko Andrijašević (Nikšić), Csaba Békés (Budapest), Rajko

Bratož (Ljubljana), Snježana Buzov (Columbus, Ohio), Svetlozar Eldarov (Sofija), Toni Filiposki

(Skopje), Aleksandar Fotić (Beograd), Alojz Ivanišević (Wien),

Egidio Ivetić (Padova), Husnija Kamberović (Sarajevo), Karl Kaser (Graz),

Irina Ognyanova (Sofija), Géza Pálffy (Budapest), Ioan-Aurel Pop (Cluj),

Nada Proeva (Skopje), Alexios Savvides (Kalamata), Vlada Stanković (Beograd),

Ludwig Steindorff (Kiel), Peter Štih (Ljubljana)

\section{Izvršna urednica za tuzemnu i inozemnu razmjenu / \\ Executive Editor for Publications Exchange \\ Kristina Milković}

Tajnik uredništva / Editorial Board Assistant
Dejan Zadro

Adresa uredništva/Editorial Board address

Zavod za hrvatsku povijest, Filozofski fakultet Zagreb, Ivana Lučića 3, HR-10 000, Zagreb

Tel. ++385 (0)1 6120150,6120158 , faks ++385 (0)1 6156879

Časopis izlazi jedanput godišnje / The Journal is published once a year

Časopis je u digitalnom obliku dostupan na / The Journal in digital form is accessible at Portal znanstvenih časopisa Republike Hrvatske „Hrčak““ http://hrcak.srce.hr/radovi-zhp

Financijska potpora za tisak časopisa / The Journal is published with the support by Ministarstvo znanosti, obrazovanja i športa Republike Hrvatske,

Časopis je indeksiran u sljedećim bazama / The Journal is indexed in the following databases:

Directory of Open Access Journals, EBSCO, SCOPUS 
Naslovna stranica

Iva Mandić

Grafičko oblikovanje i računalni slog

Ivanka Cokol

\author{
Lektura \\ Jadranka Brnčić \\ Tisak \\ Web2tisak, Zagreb \\ Naklada \\ 250 primjeraka
}

Časopis je u digitalnom obliku dostupan na Portalu znanstvenih časopisa Republike Hrvatske „Hrčak“ http://hrcak.srce.hr/radovi-zhp

The Journal is accessible in digital form at the Hrcak - Portal of scientific journals of Croatia http://hrcak.srce.hr/radovi-zhp 